\title{
Serum apolipoprotein C3 levels are negatively associated with hepatitis $B$ virus DNA in HBeAg-negative chronic hepatitis B patients
}

\author{
Yu Cui ${ }^{1+}$, Xiang-Dan Cui ${ }^{2+}$, Meng $\mathrm{Xu}^{3}$, Min Fang ${ }^{4}$ and Mei-Juan Cai ${ }^{3^{*}}$ (D)
}

\begin{abstract}
Background: Hepatitis B virus (HBV) infection remains a global health issue associated with substantial morbidity and mortality. Serum apolipoprotein C3 (ApoC3) and apolipoprotein A5 (ApoA5) levels were decreased in chronic hepatitis $B(C H B)$ patients, however the relationship between ApoC3 or ApoA5 and HBV DNA load remains elusive.

Methods: A total of $384 \mathrm{CHB}$ patients including $194 \mathrm{HBsAg}(+) \mathrm{HBeAg}(-)$ and $190 \mathrm{HBsAg}(+) \mathrm{HBeAg}(+)$ and 154 healthy individuals were recruited in our study. Serum levels of alanine aminotransferase (ALT), aspartate transaminase (AST), total cholesterol (Chol), triglycerides (TG), apolipoprotein A1 (ApoA1), apolipoprotein B (ApoB), high-density lipoproteins cholesterol (HDL-C), low-density lipoproteins cholesterol (LDL-C) and lipoprotein a (Lpa) were examined in an automatic biochemical analyzer. Apolipoprotein A5 (ApoA5) and apolipoprotein C3 (ApoC3) were detected via ELISA.

Results: Serum ApoA1, ApoB, ApoC3 and ApoA5 levels were reduced in CHB patients. In HBeAg(-) CHB patients, plasma ApoC3 levels were negatively associated with HBV DNA load $(r=0.219, P<0.001)$. But no correlation between ApoA5 and HBV DNA load was observed in CHB patients.

Conclusions: These data showed that HBV infection inhibits lipid metabolism and ApoC3 is negatively associated with HBV DNA load in HBeAg (-) CHB patients. These findings provided new evidence about the link between ApoC3-related lipid metabolism and immune response.
\end{abstract}

Keywords: Hepatitis B virus, HBeAg, ApoC3, ApoA5

\section{Introduction}

Liver is the key organ for lipoproteins synthesis, degradation and lipid metabolism [1]. Infection by hepatitis B virus (HBV) remains a global health issue associated with substantial morbidity and mortality [2], which causes various chronic liver diseases, liver cirrhosis and hepatocellular carcinoma [3]. Although some reports were focused on the pathogenesis of chronic hepatitis B (CHB) $[4,5]$, the relationship between $\mathrm{HBV}$ and lipid metabolism remains elusive.

\footnotetext{
* Correspondence: meijuancai85@163.com

† Yu Cui and Xiang-Dan Cui contributed equally to this work.

${ }^{3}$ Department of Clinical Laboratory, Qilu Hospital of Shandong University, No. 107 Wenhua Xi Road, Jinan 250012, Shandong, China

Full list of author information is available at the end of the article
}

During the process of normal transport, lipids are combined with apolipoprotein (Apo) [6]. ApoA5 and ApoC3 are important members of Apo family. ApoA5 is found to be located in ApoA1/C3/A4 gene cluster on human chromosome 11q23 [7] and is present in highdensity lipoprotein cholesterol (HDL-C), very lowdensity lipoprotein and chylomicrons [8]. ApoC3 is a 79 amino-acid glycoprotein synthesized mainly in the liver [9]. Some reports indicated that ApoC3 plays a central role in regulating the plasma metabolism of TG-rich lipoproteins (TRL), and decreases TRL hydrolysis $[5,10]$. ApoC3 and ApoA5 are associated with multiple lipid metabolism-related diseases, such as type 1 diabetes and coronary artery disease [11-13]. Although previous study showed that HBV inhibits ApoA5 and ApoC3

(C) The Author(s). 2019 Open Access This article is distributed under the terms of the Creative Commons Attribution 4.0 International License (http://creativecommons.org/licenses/by/4.0/), which permits unrestricted use, distribution, and 
promoter activity and mRNA and protein expression through its core gene [14] or X gene [15], respectively, little was revealed about the association between ApoC3 or ApoA5 and HBV replication rate in $\mathrm{CHB}$ patients.

In our study, we mainly detected the serum levels of ApoC3 and ApoA5 in CHB patients and healthy individuals. We found that the serum ApoC3 levels were negatively associated with HBV DNA load in HBeAg-negative $\mathrm{CHB}$ patients, and no significant relationship was observed between ApoA5 and HBV DNA load in CHB patients. These findings enriched the function of $\mathrm{ApoC} 3$ and provided new insight for the management of anti-viral treatment in HBV clinical practice.

\section{Materials and methods Study subjects}

A total of $384 \mathrm{CHB}$ patients and 154 healthy individuals were recruited from Qihu Hospital of Shandong University (Qingdao) between December 2016 and September 2018. There were 288 males and 250 females among 538 individuals. The CHB patients were comprised of $194 \mathrm{HBsAg}(+)$ $\mathrm{HBeAg}(-)$ and $190 \mathrm{HBsAg}(+) \mathrm{HBeAg}(+)$. CHB was diagnosed based on serum HBsAg (+) for at least 6 months. The patients who had a history of critical organs disease such as heart, brain and other chronic liver diseases that can cause metabolic lipid abnormalities were excluded. The 154 healthy individuals were comprised of sexmatched HBsAg(-) volunteers from the Medical Examination Center of Qilu Hospital of Shandong University (Qingdao). The study was approved by the Ethics Committee of Qilu Hospital of Shandong University (Qingdao) (KYLL-2016(KS)-173, http://www.qiluhospital.com/) and all subjects signed the informed consent.

\section{Biochemical testing}

Blood samples were collected from each individual after overnight fasting. After centrifugation at $3500 \mathrm{rpm}$ for 8 min, sera were collected and stored at $80^{\circ} \mathrm{C}$ for followup experiments. Serum levels of alanine aminotransferase (ALT, IFCC method), aspartate transaminase (AST, colorimetry), total cholesterol (Chol, enzymatic colorimetry), triglycerides (TG, colorimetry), total bilirubin (TBI, Diazo method) and direct bilirubin (DBI, Diazo method) were assessed using Roche Cobas c 701 (Roche, Switzerland). The levels of apolipoprotein A1 (ApoA1) and apolipoprotein B (ApoB) were examined using immunoturbidimetric method, and the serum levels of high-density lipoproteins cholesterol (HDL-C), low-density lipoproteins cholesterol (LDL-C) were detected using surfactant clearance method, and lipoprotein a (Lpa) was examined using latex immunoturbidimetry method in Roche Cobas c 701 (Roche, Switzerland).

\section{Virological assessment}

Serum levels of $\mathrm{HBsAg}$ and $\mathrm{HBeAg}$ were measured using Roche Cobas e 601 (Roche, Switzerland). HBV DNA was examined with Hepatitis B Viral Quantitative Fluorescence Diagnosis Kit (Sansure Biotech Inc., Hunan, China) by using Real-time Fluorescene Quantitative polymerase chain reaction system LightCycler 480 II (Roche, Switzerland).

\section{Enzyme-linked immunosorbent assay (ELISA) for ApoC3 and ApoA5}

Serum levels of ApoC3 and ApoA5 were assessed with the sandwich ELISA Kits (Jingmei Biological Technology Co.Ltd., Jiangsu, China) according to the protocol. The optical density (OD) value was measured at the wavelength of $450 \mathrm{~nm}$ by using Thermo Fisher Multiskan FC photometer (Thermo Fisher Scientific, Waltham, MA).

\section{Statistical analysis}

Data were expressed as means \pm standard deviations. Statistical analysis was performed by IBM SPSS Statistics 25.0 (IBM Corporation, USA) and GraphPad Prism 5.01 (GraphPad Software, Inc., California, USA). Differences were compared by a one-way analysis of variance (ANOVA), followed by LSD post hoc test. Relationship between two variables was determined by Pearson's correlation coefficient. Two tailed $P<0.05$ was considered statistically significant.

\section{Results}

\section{Baseline characteristics}

The clinical and liver biochemical profiles of participants in the study cohort were listed in Table 1 . There were 538 individuals in the study, containing 154 healthy volunteers, $194 \mathrm{HBeAg}(-) \mathrm{HBsAg}(+)$ and $190 \mathrm{HBeAg}(+)$ $\mathrm{HBsAg}(+)$ patients. No significant differences in gender, age and BMI were observed among Healthy, HBeAg (-) and HBeAg $(+)$ groups $(P>0.05)$. The serum ALT levels in $\mathrm{HBeAg}(-)$ and $\mathrm{HBeAg}(+)$ groups were significantly

Table 1 Clinical and liver biochemical profiles of participants in the study

\begin{tabular}{llll}
\hline Groups & $\begin{array}{l}\text { Healthy } \\
(n=154)\end{array}$ & $\begin{array}{l}\text { HBeAg-negative } \\
(n=194)\end{array}$ & $\begin{array}{l}\text { HBeAg-positive } \\
(n=190)\end{array}$ \\
\hline Gender (M/F) & $58 / 96$ & $104 / 90$ & $92 / 98$ \\
Age (years) & $45.31 \pm 14.84$ & $43.97 \pm 14.05$ & $39.93 \pm 12.98$ \\
BMI (kg/m $\left.{ }^{2}\right)$ & $21.91 \pm 1.01$ & $22.11 \pm 1.82$ & $22.04 \pm 1.58$ \\
ALT $(\mathrm{U} / \mathrm{L})$ & $15.52 \pm 0.76$ & $39.72 \pm 5.54^{* *}$ & $62.16 \pm 8.34^{* * \# \#}$ \\
AST $(\mathrm{U} / \mathrm{L})$ & $17.09 \pm 0.45$ & $40.87 \pm 4.16^{* *}$ & $48.39 \pm 5.00^{* *}$ \\
TBI $(\mu \mathrm{M})$ & $11.20 \pm 0.53$ & $11.27 \pm 0.75^{* *}$ & $11.78 \pm 0.85$ \\
DBI $(\mu M)$ & $4.37 \pm 0.18$ & $5.73 \pm 1.02^{* *}$ & $4.87 \pm 0.62^{*}$ \\
Log HBV DNA & & $3.82 \pm 1.70$ & $6.25 \pm 1.90^{\# \#}$ \\
\hline
\end{tabular}

${ }^{*} P<0.05,{ }^{* *} P<0.01$, compared with Healthy group; ${ }^{\# \#} P<0.01$, compared with $\mathrm{HBeAg-negative} \mathrm{group.} \mathrm{BMI,} \mathrm{Body} \mathrm{mass} \mathrm{index}$ 
higher than those in Healthy group $(P<0.01)$, and the level of ALT in $\mathrm{HBeAg}(+)$ displayed the highest. Similarly, compared with Healthy group, the levels of AST in $\operatorname{HBeAg}(-)$ and $\operatorname{HBeAg}(+)$ were enhanced $(\mathrm{P}<0.01)$, however there was no significant difference between $\mathrm{HBeAg}(-)$ and $\mathrm{HBeAg}(+)$ groups $(P>0.05)$. No significant difference on TBI levels was observed between healthy and $\operatorname{HBeAg}(+)$ groups $(\mathrm{P}>0.05)$, but the serum TBI level in $\mathrm{HBeAg}(-)$ group was higher than that in Healthy group $(P<0.01)$. Compared with Healthy group, the levels of DBI in $\mathrm{HBeAg}(-)$ and $\mathrm{HBeAg}(+)$ groups were significantly higher than those in Healthy group $(P<0.01, P<0.05)$. Log HBV DNA in HBeAg $(+)$ group was higher than that in $\operatorname{HBeAg}(-)$ group $(\mathrm{P}<0.01)$.

\section{The plasma levels of TG, HDL-C and LDL-C were} decreased in CHB patients

We further investigated the levels of Chol, TG, HDL-C and LDL-C in Healthy, $\mathrm{HBeAg}(-)$ and $\mathrm{HBeAg}(+)$ groups. As shown in Fig. 1a, compared with Healthy group, the levels of Chol in $\mathrm{HBeAg}(-)$ and $\mathrm{HBeAg}(+)$ groups were significantly enhanced $(P<0.05, P<0.01)$, and no significant difference was observed between $\operatorname{HBeAg}(-)$ and HBeAg $(+)$ groups $(P>0.05)$. In Fig. $1 b$, the serum TG in Healthy group was the highest, and the serum TG in
$\mathrm{HBeAg}(+)$ group was significantly lower than that in HBeAg $(-)(P<0.01)$. Compared with healthy group, the serum HDL-C and LDL-C levels in both HBeAg(-) and $\operatorname{HBeAg}(+)$ groups were significantly reduced $(P<0.01)$, and there was no significant difference between $\operatorname{HBeAg}(-)$ and $\mathrm{HBeAg}(+)$ groups $(P>0.05)$.

The serum ApoA1, ApoB, ApoA5 and ApoC3 levels were reduced in $\mathrm{CHB}$ patients

As shown in Fig. 2a-d, the serum levels of ApoA1, ApoB, ApoA5 and $\mathrm{ApoC} 3$ in $\mathrm{HBeAg}(-)$ and $\mathrm{HBeAg}(+)$ groups were significantly blocked than those in Healthy group $(P<0.01, \mathrm{P}<0.01, P<0.05, \mathrm{P}<0.01)$, and no significant differences between $\operatorname{HBeAg}(-)$ and $\operatorname{HBeAg}(+)$ groups were detected $(P>0.05)$. As displayed in Fig. $2 \mathrm{e}$, the serum Lpa level in $\operatorname{HBeAg}(+)$ was significantly lower than that in Healthy group $(P<0.01)$, and there was no significant difference between Healthy and $\operatorname{HBeAg}(-)$ groups $(P>0.05)$.

\section{Serum ApoC3 levels were negatively associated with HBV} DNA load in $\mathrm{HBeAg}(-)$ patients

We further investigated the relationship between ApoC3 or ApoA5 and HBV DNA load in CHB patients by using double variables correlation in SPSS software in Fig. 3.

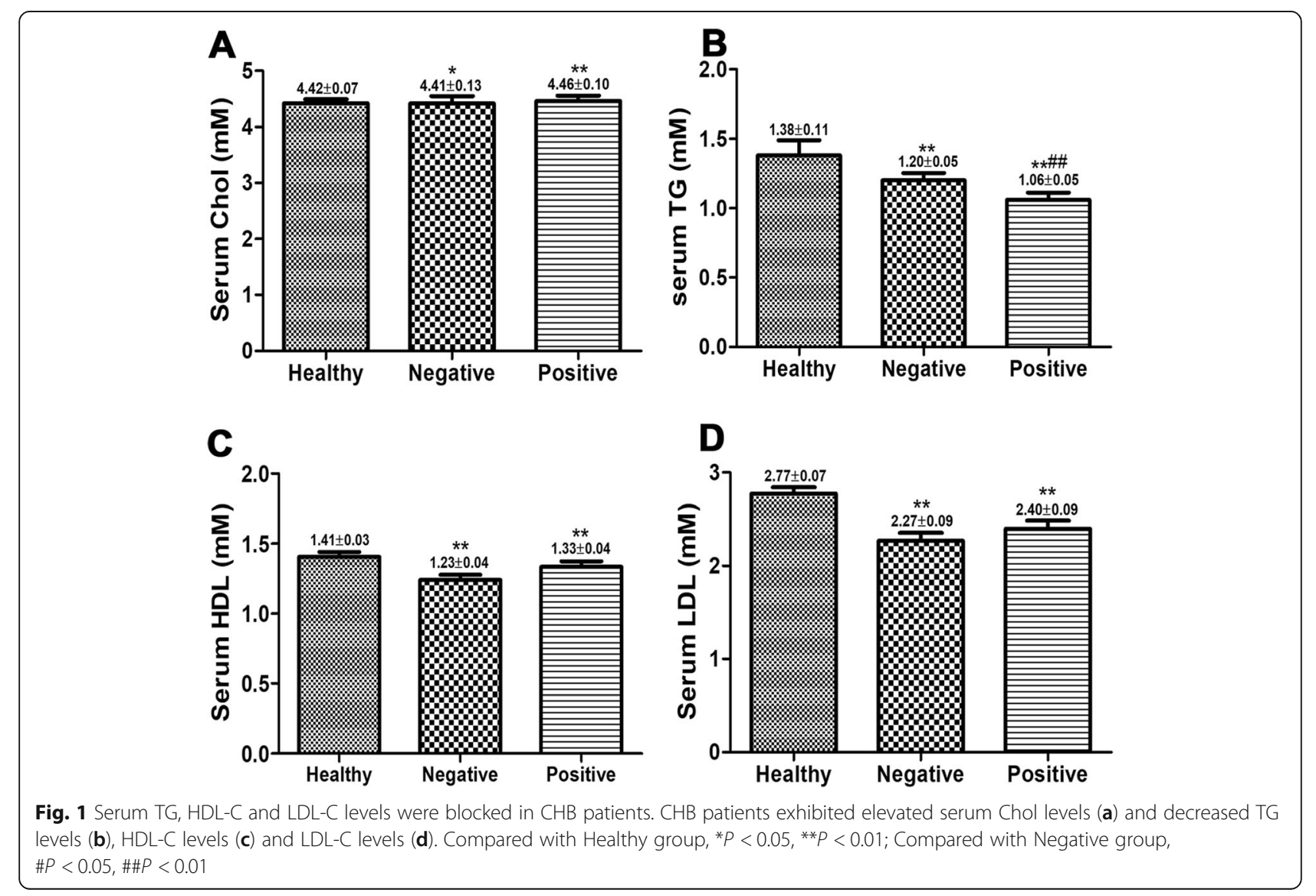



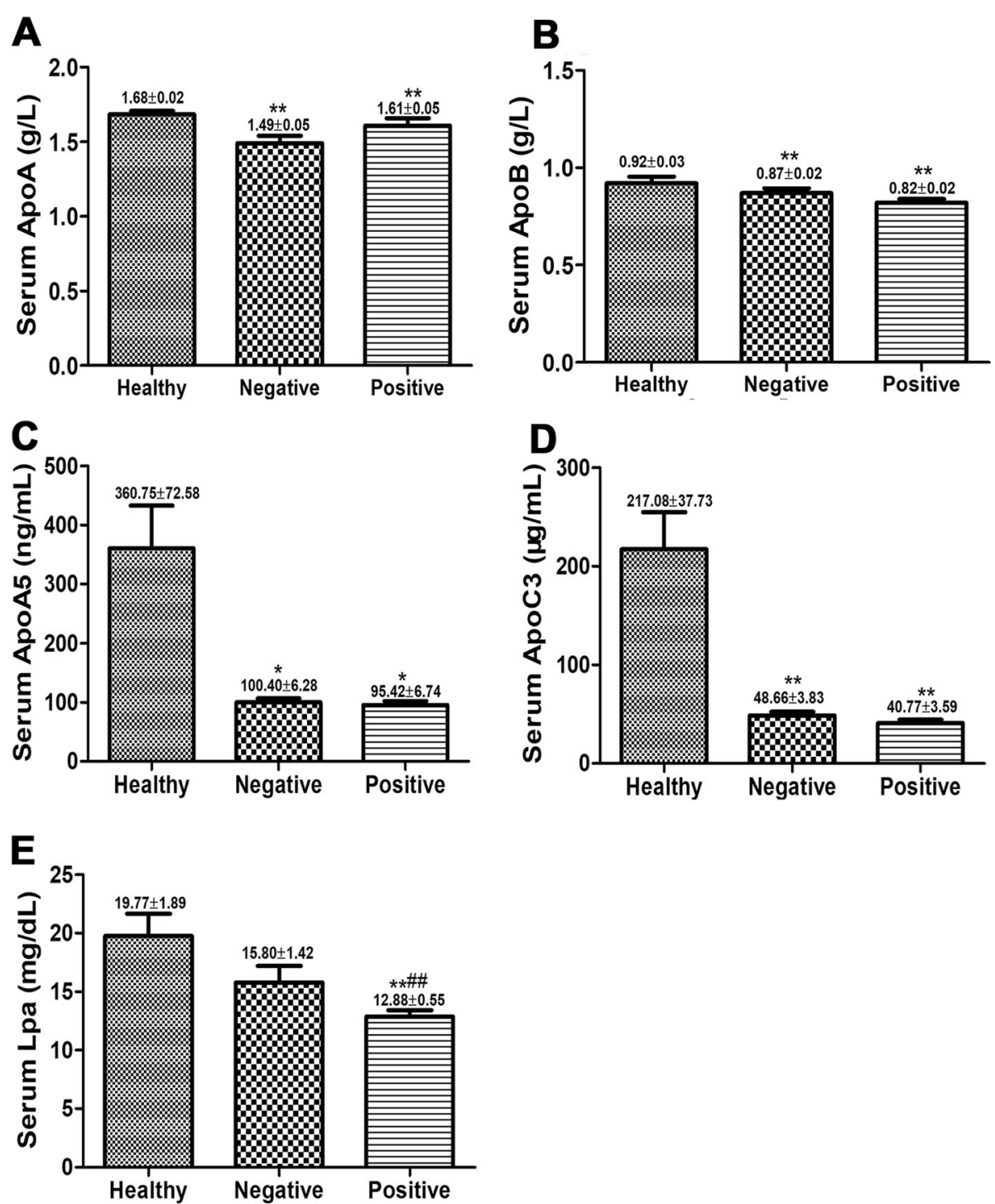

Fig. 2 Serum ApoA1, ApoB, ApoA5, ApoC3 and Lpa levels were decreased in CHB patients. Compared with Healthy group, ApoA1 (a), ApoB (b), ApoA5 (c), ApoC3 (d) and Lpa (e) levels in CHB patients were significantly blocked. Compared with Healthy group, ${ }^{*} P<0.05$, ${ }^{* *} P<0.01$; Compared with Negative group, $\# P<0.05$, \#\# $<0.01$

As shown in Fig. 3a and b, negative correlation between ApoC3 and HBV DNA load was observed in HBeAg $(-)$ patients $(P<0.001)$, but not in HBeAg $(+)$ patients $(P=$ 0.073). In Fig. $3 c$ and d, there was no significant correlation between ApoA5 level and HBV DNA load in HBeAg $(-)$ and HBeAg $(+)$ patients $(P=0.489, P=0.712)$. These data showed the negative association between serum ApoC3 levels and HBV DNA load in $\mathrm{HBeAg}(-)$ patients.

\section{Serum ALT, TG, ApoC3 and Lpa levels were correlated} with HBV DNA load

We performed receiver operating characteristic (ROC) curve and chose the median value of $3.97 \log$ HBV DNA as a cutoff point in $\mathrm{CHB}$ patients. In Table 2, there were no significant differences on age, BMI, AST, TBI, DBI, Chol, HDL, LDL, ApoA1, ApoB and ApoA5 between two groups $(\log$ HBV DNA < = 3.97 and $>3.97)$. However, the serum ALT in (log HBV DNA $<=3.97)$ group was significantly lower than that in (log HBV DNA > 3.97) group, and serum TG, ApoC3 and Lpa levels in (log HBV DNA $<=3.97$ ) group were significantly higher than those in (log HBV DNA > 3.97) group. These data showed the relationship between ALT, TG, ApoC3 or Lpa and HBV DNA load.

\section{Discussion}

Chronic liver diseases can interfere with hepatic metabolism of lipids, lipoproteins or apoliproteins [16]. HBV 

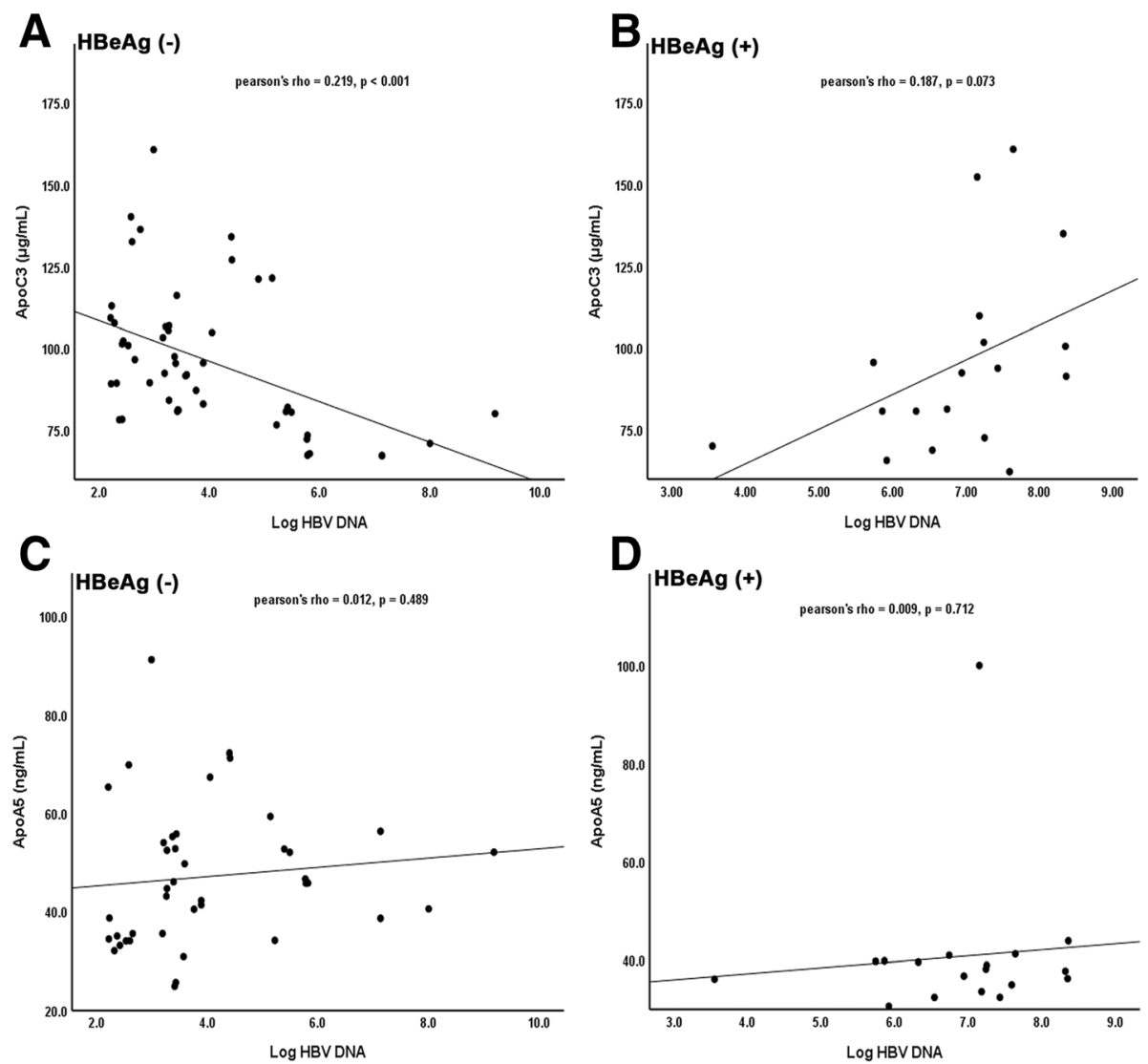

Fig. 3 Serum ApoC3 levels were negatively associated with HBV DNA load in HBeAg (-) CHB patients. A and B displayed the relationship between ApoC3 and HBV DNA load in HBeAg (-) and HBeAg (+) CHB patients. C and D exhibited the relationship between ApoA5 and HBV DNA load in HBeAg (-) and HBeAg (+) CHB patients. Relationship between two variables was determined by Pearson's correlation coefficient

infection is reported to be a major cause of chronic liver disease [17], which indicates the close relationship between HBV and lipid metabolism. In our study, we examined the serum levels of ALT, AST, TBI, DBI, Chol, TG, HDL-C, LDL-C, ApoA1, ApoB, ApoC3, ApoA5 and Lpa in healthy individuals and $\mathrm{CHB}$ patients. Biochemical test and ELISA results showed that serum ALT, AST and Chol levels were elevated, but serum TG, HDL-C, LDL-C, ApoA1, ApoB, ApoC3 and Lpa levels were decreased in CHB patients. Pearson's correlation analysis indicated the negative association between serum ApoC3 and HBV DNA load in HBeAg (-) CHB patients. These findings provided new evidence about the effect of HBV infection on lipid metabolism and indicated the relationship between ApoC3 and HBV DNA load.

Apoliproteins exert enzyme cofactors, receptor ligands or lipid transfer carriers via binding lipids to form lipoproteins [18]. Apoliproteins family contains several sub-classes, including ApoA, ApoB, ApoC and so on. Previous study showed that plasma ApoA1, ApoB and ApoA5 levels are decreased in $\mathrm{CHB}$ patients
$[14,19,20]$. It is indicated that HBV suppresses the synthesis and secretion of ApoA1 by inducing the hypermethylation of the ApoA1 promoter [21], inhibits the expression of $A p o B$ via the suppression of microsomal triglyceride transfer protein [22] and blocks the levels of ApoA5 through its core gene [14]. In our study, we found that serum ApoA1, ApoB and ApoA5 levels were decreased in $\mathrm{HBeAg}(-)$ and HBeAg (+) CHB patients, which were in agreement with the previous research. In addition, we also found that plasma HDL-C and LDL-C levels were reduced in $\mathrm{CHB}$ patients. It is reported that ApoA1 is a major protein component of HDL-C [21], ApoB is the major structural protein associated with LDL-C [23], and ApoA5 is involved in elevating HDL-C [14]. Thus the decrease on HDL-C and LDL-C content might be related with the decrease on ApoA1, ApoB and ApoA5 in $\mathrm{CHB}$ patients. However, further experiments need to be carried out to explore the detailed mechanism.

ApoC3 is involved in regulating the plasma metabolism of triglyceride and TG-rich lipoproteins (TRL) by inhibiting the clearance of TRL particles [24]. Previous 
Table 2 Association of Clinical and liver biochemical profiles of chronic hepatitis B with HBV DNA levels

\begin{tabular}{llll}
\hline Log HBV DNA & $\begin{array}{l}<=3.97 \\
(n=248)\end{array}$ & $\begin{array}{l}>3.97 \\
(n=136)\end{array}$ & $P$ \\
\hline Gender (M/F) & $141 / 107$ & $55 / 81$ & - \\
Age (years) & $41.77 \pm 13.68$ & $41.27 \pm 13.38$ & 0.474 \\
BMI (kg/m²) & $21.98 \pm 1.25$ & $22.23 \pm 1.52$ & 0.582 \\
ALT (U/L) & $50.88 \pm 2.05$ & $66.50 \pm 4.35$ & $\mathbf{0 . 0 4 4}$ \\
AST $(\mathrm{U} / \mathrm{L})$ & $44.61 \pm 3.25$ & $54.39 \pm 6.10$ & 0.079 \\
TBI $(\mu \mathrm{M})$ & $11.52 \pm 0.57$ & $12.67 \pm 0.86$ & 0.459 \\
DBI $(\mu M)$ & $5.30 \pm 0.60$ & $5.52 \pm 0.64$ & 0.801 \\
Chol $(\mathrm{mM})$ & $4.44 \pm 0.08$ & $4.37 \pm 0.09$ & 0.917 \\
TG $(\mathrm{mM})$ & $1.29 \pm 0.06$ & $1.09 \pm 0.02$ & $\mathbf{0 . 0 3 2}$ \\
HDL $(\mathrm{mM})$ & $1.29 \pm 0.03$ & $1.30 \pm 0.04$ & 0.964 \\
LDL $(\mathrm{mM})$ & $2.33 \pm 0.06$ & $2.30 \pm 0.08$ & 0.975 \\
ApoA $(\mathrm{g} / \mathrm{L})$ & $1.55 \pm 0.04$ & $1.54 \pm 0.05$ & 0.826 \\
ApoB $(\mathrm{g} / \mathrm{L})$ & $0.90 \pm 0.02$ & $0.88 \pm 0.03$ & 0.794 \\
ApoA5 $(\mathrm{ng} / \mathrm{mL})$ & $100.18 \pm 2.84$ & $105.55 \pm 3.69$ & 0.607 \\
ApoC3 $(\mu \mathrm{gg} / \mathrm{mL})$ & $53.29 \pm 4.26$ & $45.58 \pm 2.64$ & $\mathbf{0 . 0 4 5 *}$ \\
Lpa $(\mathrm{mg} / \mathrm{mL})$ & $14.29 \pm 0.75$ & $13.19 \pm 0.54$ & $\mathbf{0 . 0 1 3 *}$ \\
\hline
\end{tabular}

${ }^{*} P<0.05, B M l$ Body mass index

study has clearly shown that a decrease in ApoC3 is associated with a significant decrease in TG levels [25]. It is indicated that HBV down-regulated the synthesis and secretion of ApoC3 via its $\mathrm{X}$ gene and lower serum levels of ApoC3 and TG were observed in $\mathrm{CHB}$ patients [15]. In our study, we found that serum ApoC3 and TG levels in $\mathrm{CHB}$ patients were decreased, which is in accordance with the above results. These results provided new evidence about the physiological function of ApoC3 and confirmed its promise as a valid therapeutic target for TG-lowering. In addition, we found that serum ApoC3 level is negatively associated with the HBV DNA load in HBeAg (-) CHB patients, not in HBeAg (+) $\mathrm{CHB}$ patients, which suggests the function of ApoC3 is related with the status of $\mathrm{HBeAg}$. $\mathrm{HBeAg}$ is a nonparticulate version of the $\mathrm{HBV}$ nucleocapsid protein, which is secreted at an early stage in the HBV replication cycle [26]. It is reported that an $\mathrm{HBeAg}(-)$ status and intermediate HBV DNA levels are associated with severe diseases in CHB patients [27]. And the presence of steatosis is associated with various host factors and HBeAg negativity [28]. These data revealed the key role of $\mathrm{HBeAg}$ during $\mathrm{HBV}$ infection. HBeAg contributes to the establishment and persistence of chronic infection through complex inflammatory and immune response [29]. For example, HBV inhibits LPS-induced NLRP3 inflammasome activation and IL-1B production by HBeAg, not HBsAg [30]. Taken together, our study combined the lipid metabolism with immune response in
CHB patients, which shed new light for HBV diagnosis and therapy. However, more experiments need to be performed to elucidate the molecular effects of $\mathrm{HBeAg}$ on ApoC3 expression.

\section{Conclusions}

In summary, we mainly summarized the serum levels of Apo members (ApoA1, ApoB, ApoC3, ApoA5) in CHB patients and revealed the negative relationship between ApoC3 and HBV DNA load in $\mathrm{HBeAg}(-) \mathrm{CHB}$ patients. These findings indicated the effect of HBV infection on lipid metabolism and determined ApoC3 as a serum marker to facilitate the management of $\mathrm{CHB}$ in clinical practice or a potential helpful agent in $\mathrm{CHB}$ treatment. However, there are some limitations in our study. Firstly, the number of $\mathrm{CHB}$ patients in the study cohort is relative insufficient. Our results need to be confirmed in a larger set of patients. Secondly, the CHB patients in our study are mainly focused on shandong peninsula. This study has certain regional specificity. Thirdly, although we revealed the negative association between ApoC3 and HBV DNA load in HBeAg (-) CHB patients, the detailed mechanism remains elusive.

\section{Abbreviations}

ALT: alanine aminotransferase; ApoA1: Apolipoprotein A1;

ApoA5: Apolipoprotein A5; ApoB: Apolipoprotein B; ApoC3: Apolipoprotein

C3; AST: Aspartate transaminase; BMl: body Mass index; CHB: Chronic

hepatitis B; Chol: Total cholesterol; DBI: Direct bilirubin; HBV: Hepatitis B virus; HDL-C: High-density lipoprotein cholesterol; LDL-C: Low-density lipoprotein cholesterol; TBI: Total bilirubin; TG: Triglycerides; TRL: TG-rich lipoproteins

\section{Authors' contributions}

CY and CXD performed data collection, analyzed data and wrote the original manuscript; XM carried out biochemical test and analyzed data; FM performed ELISA; CMJ provided funding support, designed the experiments, participated in statistical analysis of data and revised the manuscript. All authors have read and approved the final manuscript.

\section{Funding}

This study was supported by Qingdao Applied Basic Research Source Innovation Plan (No. 17-1-1-43-jch), Qingdao Outstanding Health Professional Development Fund, National Natural Science Fund (No.81602271) and the Key Research and Development Project of Shandong Province (No. 2017GSF218108).

\section{Availability of data and materials}

All data generated or analyzed during this study are included in this published article.

\section{Ethics approval and consent to participate}

This work was approved by the Ethical Committee of Qilu Hospital of Shandong University. All subjects signed the informed consent.

Consent for publication

Not applicable.

\section{Competing interests}

The authors declare that they have no competing interests.

\section{Author details}

${ }^{1}$ Department of Obstetrics, Yantai Yuhuangding Hospital, Qingdao University, Yantai, China. ${ }^{2}$ Department of Gastroenterology, Qilu Hospital of Shandong University, Jinan, China. ${ }^{3}$ Department of Clinical Laboratory, Qilu Hospital of 
Shandong University, No. 107 Wenhua Xi Road, Jinan 250012, Shandong, China. ${ }^{4}$ Department of Gynaecology, Qingdao Women's and Children's Hospital, Qingdao University, Qingdao, China.

Received: 11 December 2018 Accepted: 4 June 2019

Published online: 11 June 2019

\section{References}

1. Hoover-Plow J, Huang M. Lipoprotein(a) metabolism: potential sites for therapeutic targets. Metabolism. 2013;62:479-91.

2. Li N, Li L, Chen Y. The identification of Core gene expression signature in hepatocellular carcinoma. Oxidative Med Cell Longev. 2018;2018:3478305.

3. Aslam A, Campoverde Reyes KJ, Malladi VR, Ishtiaq R, Lau DTY. Management of chronic hepatitis B during pregnancy. Gastroenterol Rep (Oxf). 2018;6: 257-62.

4. Ponziani FR, Pecere S, Gasbarrini A, Ojetti V. Physiology and pathophysiology of liver lipid metabolism. Expert Rev Gastroenterol Hepatol. 2015;9:1055-67.

5. Miller M, Stone NJ, Ballantyne C, Bittner V, Criqui MH, Ginsberg HN, Goldberg AC, Howard WJ, Jacobson MS, Kris-Etherton PM, et al. Triglycerides and cardiovascular disease: a scientific statement from the American Heart Association. Circulation. 2011:123:2292-333.

6. Gonzales JC, Gordts PL, Foley EM, Esko JD. Apolipoproteins E and AV mediate lipoprotein clearance by hepatic proteoglycans. J Clin Invest. 2013; 123:2742-51.

7. Pennacchio LA, Rubin EM. Apolipoprotein A5, a newly identified gene that affects plasma triglyceride levels in humans and mice. Arterioscler Thromb Vasc Biol. 2003;23:529-34

8. O'Brien PJ, Alborn WE, Sloan JH, Ulmer M, Boodhoo A, Knierman MD, Schultze AE, Konrad RJ. The novel apolipoprotein A5 is present in human serum, is associated with VLDL, HDL, and chylomicrons, and circulates at very low concentrations compared with other apolipoproteins. Clin Chem. 2005;51:351-9.

9. Kohan AB. Apolipoprotein C-III: a potent modulator of hypertriglyceridemia and cardiovascular disease. Curr Opin Endocrinol Diabetes Obes. 2015;22: 119-25

10. Marcoux C, Tremblay M, Fredenrich A, Davignon J, Cohn JS. Lipoprotein distribution of apolipoprotein C-III and its relationship to the presence in plasma of triglyceride-rich remnant lipoproteins. Metabolism. 2001;50:112-9.

11. Yang M, Zhao H, Ai H, Zhu H, Wang S, Bao Y, Li Y. Alantolactone suppresses APOC3 expression and alters lipid homeostasis in L02 liver cells. Eur J Pharmacol. 2018:828:60-6.

12. Wang $Y$, Shen L, Xu D. Aerobic exercise reduces triglycerides by targeting apolipoprotein C3 in patients with coronary artery disease. Clin Cardiol. 2018.

13. Raj R, Bhatti JS, Badada SK, Ramteke PW. Genetic basis of dyslipidemia in disease precipitation of coronary artery disease (CAD) associated type 2 diabetes mellitus (T2DM). Diabetes Metab Res Rev. 2015;31:663-71.

14. Zhu C, Gao G, Song H, Xu F, Wu K, Liu X. Hepatitis B virus inhibits apolipoprotein A5 expression through its core gene. Lipids Health Dis. 2016; $15: 178$

15. Zhu C, Zhu H, Song H, Xu L, Li L, Liu F, Liu X. Hepatitis B virus inhibits the in vivo and in vitro synthesis and secretion of apolipoprotein C3. Lipids Health Dis. 2017:16:213.

16. Gu JG, Zhu CL, Cheng DZ, Xie Y, Liu F, Zhou X. Enchanced levels of apolipoprotein M during HBV infection feedback suppresses HBV replication. Lipids Health Dis. 2011;10:154.

17. Ganem D, Prince AM. Hepatitis B virus infection--natural history and clinical consequences. N Engl J Med. 2004;350:1118-29.

18. Norum KR, Glomset JA, Nichols AV, Forte T, Albers JJ, King WC, Mitchell CD, Applegate KR, Gong EL, Cabana V, et al. Plasma lipoproteins in familial lecithin: cholesterol acyltransferase deficiency: effects of incubation with lecithin: cholesterol acyltransferase in vitro. Scand J Clin Lab Invest Suppl. 1975;142:31-55

19. Mohamadkhani A, Jazii FR, Sayehmiri K, Jafari-Nejad S, Montaser-Kouhsari L Poustchi H, Montazeri G. Plasma myeloperoxidase activity and apolipoprotein A-1 expression in chronic hepatitis B patients. Arch Iran Med. 2011:14:254-8.

20. Janicko M, Senajova G, Drazilova S, Veseliny E, Fedacko J, Siegfried L, Kristian P, Virag L, Pella D, Marekova M, et al. Association between metabolic syndrome and hepatitis B virus infection in the Roma population in eastern Slovakia: a population-based study. Cent Eur Public Health. 2014;22 Suppl:S37-42.
21. Wang Y, Hao J, Liu X, Wang H, Zeng X, Yang J, Li L, Kuang X, Zhang T. The mechanism of apoliprotein A1 down-regulated by hepatitis $B$ virus. Lipids Health Dis. 2016;15:64.

22. Jiang $W$, Zheng $L$, Yang Q, Huang Z, Wang X. Investigation into the effect of hepatitis B virus on apoliprotein A1 expression and its mechanism. Lipids Health Dis. 2014;13:130.

23. Wang FB, Zhu CL, Liu X, Gao GS. HBV inhibits apoB production via the suppression of MTP expression. Lipids Health Dis. 2011;10:207.

24. Ramms B, Gordts P. Apolipoprotein C-III in triglyceride-rich lipoprotein metabolism. Curr Opin Lipidol. 2018;29:171-9.

25. Gouni-Berthold I. The role of antisense oligonucleotide therapy against apolipoprotein-CIII in hypertriglyceridemia. Atheroscler Suppl. 2017;30:19-27.

26. Lahlali T, Berke JM, Vergauwen K, Foca A, Vandyck K, Pauwels F, Zoulim F, Durantel D. Novel potent capsid assembly modulators regulate multiple steps of the hepatitis B virus life cycle. Antimicrob Agents Chemother. 2018;62

27. Zhang S, Wang F, Zhang Z. Current advances in the elimination of hepatitis B in China by 2030. Front Med. 2017;11:490-501.

28. Poortahmasebi V, Alavian SM, Keyvani H, Norouzi M, Mahmoodi M, Jazayeri SM. Hepatic steatosis: prevalence and host/viral risk factors in Iranian patients with chronic hepatitis B infection. Asian Pac J Cancer Prev. 2014;15:3879-84.

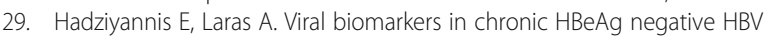
infection. Genes (Basel). 2018;9.

30. Yu X, Lan P, Hou X, Han Q, Lu N, Li T, Jiao C, Zhang J, Zhang C, Tian Z. HBV inhibits LPS-induced NLRP3 inflammasome activation and IL-1 beta production via suppressing the NF-kappaB pathway and ROS production. J Hepatol. 2017:66:693-702.

\section{Publisher's Note}

Springer Nature remains neutral with regard to jurisdictional claims in published maps and institutional affiliations.

Ready to submit your research? Choose BMC and benefit from:

- fast, convenient online submission

- thorough peer review by experienced researchers in your field

- rapid publication on acceptance

- support for research data, including large and complex data types

- gold Open Access which fosters wider collaboration and increased citations

- maximum visibility for your research: over $100 \mathrm{M}$ website views per year

At BMC, research is always in progress.

Learn more biomedcentral.com/submissions 